\title{
RECENT SCIENTIFIC INQUIRIES IN PARLIAMENT
}

\begin{abstract}
A $\mathrm{T}$ question time in the House of Commons on May 16, the Parliamentary Secretary for Science, Mr. D. Freeth, was faced with no fewer than 39 questions relating to scientific matters, ranging from the performance of the reactors at Calder Hall and Chapel Cross, progress with production of nuclear reactors for research and teaching purposes, to arterial disease and fire hazards of domestic equipment.

In the course of his replies, Mr. Freeth said that rather more than three-quarters of Great Britain has been covered by the Geological Survey in the primary 6 -in. survey. At the present rate of progress the primary 6 -in. solid and drift survey would be completed in about 55 years; it is hoped to reduce this to $35-40$ years. Nearly as much secondary survey as primary survey is being carried out, and work is now being done on the more difficult mountainous regions. The Survey has also prepared the tectonic map of the United Kingdom as part of a co-operative scheme for a tectonic map of Europe.

On research into coal utilization, Mr. Freeth said that besides the British Coal Utilization Research Association, the British Coke Research Association and the Coal Tar Research Association are primarily concerned with the utilization of coal. All three research associations are doing very valuable work and there is a great deal of co-operation between them and between the National Coal Board, the Central Electricity Generating Authority, the Gas Council and the appliance and equipment makers. The total income last year of the Coal Utilization Research Association was $£ 450,000$, of the Coke Research Association more than $£ 150,000$ and of the Coal Tar Research Association less than $£ 113,000$. There was the fullest possible co-ordination on the matter between the Minister for Science and the Minister of Power.

Mr. Freeth was also asked what research was being conducted into the better use of the mineral resources of Britain; he referred to the basic information supplied by the Geological Survey and Museum in its maps and memoirs. The Warren Spring Laboratory and the National Chemical Laboratory undertake research on processing ores and extracting metals, and various research associations, industrial
\end{abstract}

firms and universities undertake research into the better use of minerals.

Asked as to the action taken to apply scientific development to the machine tool industry, Mr. Freeth said that besides the scientific development work of the Machine Tool Industry Research Association and the Production Engineering Research Association, research of direct value to such scientific development was carried out at the National Engineering Laboratory and the National Physical Laboratory. In addition, 12 grants totalling more than $£ 170,000$ have been made for research and development work in this field in the past two years to six universities and two colleges of technology in England and Wales. The Machine Tool Advisory Council is reviewing progress made in implementing the recommendations of the Mitchell Sub-Committee. Mr. Freeth also referred to a ten-fold increase in the accuracy of large modern gears over the past twenty years, to which research and development work at the National Physical Laboratory and the National Engineering Laboratory had contributed. Gears up to $16 \mathrm{ft}$. in diameter can now be made with an error of one-quarter of a thousandth of an inch from the true form and spacing of the teeth and the automatic error-correcting system developed recently by the National Engineering Laboratory have been applied to a gear-cutting machine.

While the Department of Scientific and Industrial Research has not sponsored any research into the use and operation of multi-purpose pipe-lines for the transport of both liquids and solids, it is itself carrying out research into the subject, and the Department is always willing to discuss with industry the part it could play in assisting research and developing techniques in every field.

In response to a specific request which had been made for a breakdown of the figure of $£ 42.9$ million for Government expenditure on civil research and development in 1958-59 given in the report of the Advisory Council on Scientific Policy, Mr. Freeth gave the following figures for the source of the funds concerned: defence departments, $£ 2.9$ million; civil departments, $£ 34.7$ million; private industry, $£ 4.5$ million; other organizations, $£ 0.8$ million.

\section{MAWSON INSTITUTE OF ANTARCTIC RESEARCH}

$\mathrm{O}$ N April 15 the Prime Minister of Australia (the Rt. Hon. R. G. Menzies) inaugurated, within the University of Adelaide, the Mawson Institute of Antarctic Research. In his inaugural address $\mathrm{Mr}$. Menzies referred to the great ochievements of Sir Douglas Mawson in science and exploration, and affirmed that Mawson had accomplished so much because he possessed, in the highest degree, the qualities of imagination, courage and endurance.

The University of Adelaide has established the Institute, believing that it would provide the best means to commemorate one of its most distinguished members. Mawson joined the University staff in 1905 as lecturer in mineralogy and petrology. In 1921, he was appointed professor of geology and mineralogy, and he retired in 1952. He remained a member of the University Council until his death in 1958.

The main purpose of the Institute will be to foster polar studies and research. In order to do this it will maintain and develop reference collections of geological and biological materials from the Antarctic. 